\title{
Social challenges and progress in IBSA
}

\author{
Manmohan Agarwal $^{\mathrm{a}}$, Hany Besada ${ }^{\mathrm{b} *}$ and Lyal White \\ ${ }^{a}$ Centre for International Governance Innovation (CIGI), New Delhi, India; \\ ${ }^{b}$ The North-South Institute (NSI), Ottawa, Ontario, Canada; \\ ${ }^{c}$ Gordon Institute of Business Science (GIBS), University of Pretoria, South Africa \\ ${ }^{*}$ Corresponding author. Email: hgbesada@gmail.com
}

The India-Brazil-South Africa (IBSA) Dialogue Forum was launched in June 2003 to push for these countries' bids for a place on the United Nation' Security Council, but IBSA's attention has shifted over time towards development and economic reform. This article discusses the progress in addressing social development challenges within the member countries of IBSA. It examines the social achievements of IBSA members, in the context of their economic performance and the Millennium Development Goals. It also assesses the forces which propel these societies' social policies, especially the influence of civil society, and whether there has been benefit in this regard in their collaboration within the IBSA forum. Their experiences show the critical importance of civil society in design and execution of programmes directed towards the poor, an important factor to be kept in mind by multilateral and bilateral agencies involved in poverty alleviation projects in developing countries. The three nations could cooperate to share ideas for effective social welfare programmes, and join together in multilateral forums to form a powerful voice for change.

Keywords: IBSA; India; Brazil; South Africa; G-20; Millennium Development Goals (MDGs); social programmes; multilateral cooperation

\section{Introduction ${ }^{1}$}

This article discusses the progress in addressing social development challenges within the member countries of IBSA. IBSA is a relatively new grouping formed by India, Brazil and South Africa in June 2003 as part of a concerted effort to reform the United Nations, particularly the Security Council, on the basis of respect for international law and the sovereignty of countries.

As is true for some other groupings of emerging economies, such as BRIC (Brazil, Russia, India and China) or BASIC (Brazil, South Africa, India and China), the original motivation behind IBSA was a concern about security issues affecting the member countries. IBSA is distinctive, however, in that it is a group of democracies, and over time it has evolved into a group aimed at addressing development and social problems of developing countries through South-South cooperation. The most recent IBSA gatherings have revealed a strong commitment to issues related to the fields of technology, food security and renewable energy. With the inclusion of developing countries, including the IBSA members, in the G20, which has arguably replaced the G8 as the focal point for international coordination, IBSA has the additional opportunity to play a part in re-shaping international economic governance. ${ }^{2}$ 
The formation of IBSA dovetailed with a renewed emphasis on social goals by the international community in the early part of the new millennium, as manifested in the Poverty Reduction Strategy Papers of the World Bank and the International Monetary Fund and the enunciation of the Millennium Development Goals (MDGs) by the UN. Consequently, an examination of the social achievements of IBSA members, in the context of their economic performance and the MDGs, is due. We examine the forces which propel these societies' social policies, especially the influence of civil society and how far political parties accept the social goals of these groups, and whether there has been benefit in this regard in their collaboration within the IBSA forum.

The first section creates a context for this discussion through an overview of the economic performance of the world economy over the previous four decades, to provide a long term view. The second section analyses the economic performance of IBSA in that context, whereas the third section discusses the social achievements and challenges facing IBSA within the framework of the MDGs. The fourth section analyses the social and political forces pushing the social objectives and programmes of these governments, and the fifth section discusses how these three economies can learn from each other's experiences and cooperate in achieving their goals. The conclusion includes comments about the policies that may be necessary to achieve the MDGs, and lessons for other countries in their regions.

\section{Growth of the world economy}

\section{Deceleration in the world economy: lagging growth in Africa and Latin America}

The world economy, which had grown at an unprecedented rate for a quarter of a century after the end of the Second World War, stuttered after the oil price crisis of 1973-1974. ${ }^{3}$ The crisis profoundly altered the structure of the world economy, and its performance over the long run. Broadly speaking, growth rates declined, inflation rates worsened and efficiency of capital, as measured by the incremental capital output ratio (ICOR), declined. This decline in the ICOR was more responsible for the lower growth rates than changes in the investment to gross domestic product (GDP) ratio. ${ }^{4}$

Developing countries, except Asia, performed poorly in the closing decades of the $20^{\text {th }}$ century (see Table 1). ${ }^{5}$ The economies of East Asia and the Pacific (EAP)

Table 1. Average annual growth of per capita income

\begin{tabular}{lccccc}
\hline Region & $1965-1973$ & $1974-1892$ & $1983-1990$ & $1991-2000$ & 2000-2007 \\
\hline World & 3.3 & 0.8 & 1.8 & 1.2 & 1.9 \\
High income & 4.3 & 1.6 & 3.0 & 1.7 & 1.7 \\
LAC & 3.6 & 1.5 & -0.2 & 1.7 & 2.1 \\
SSA & 2.3 & 0.1 & -1.1 & -0.4 & 2.5 \\
MNA & - & 1.3 & -0.5 & 1.1 & 2.5 \\
SAS & 0.2 & 2.0 & 3.5 & 3.2 & 5.5 \\
EAP & 4.5 & 4.5 & 6.3 & 6.0 & 7.9 \\
\hline
\end{tabular}

Notes: EAP, East Asia and the Pacific (EAP); SAS, South Asia; LAC, Latin America and the Caribbean; SSA, sub-Sahara Africa; and MNA, Middle East and North Africa.

Source: World Bank World Developments Indicators 2004. Washington, DC: World Bank; World Bank World Developments Indicators 2007. Washington, DC: World Bank; World Bank World Developments Indicators 2009. Washington, DC: World Bank. 
continued to grow very rapidly and growth in South Asia (SAS) accelerated as India and Bangladesh, in particular, did better. Economic performance improved in Latin America and the Caribbean (LAC) and in sub-Sahara Africa (SSA) in the 1990s, though still lagged behind their performance in the 1960s and 1970s, and accordingly, social progress was hampered. Overall, average annual growth in per capita income in SSA countries was only about $0.25 \%$ over almost four decades, and $1.8 \%$ for the LAC region.

Consequently, the gap between incomes in the developed economies of the Organisation for Economic Co-operation and Development (OECD) countries and the developing economies of in Latin America, Africa and the Middle East increased, belying earlier hopes of convergence. ${ }^{6}$ Growth rates fell for most regions of the world as the ICOR was almost halved, except in Asia. The investment ratios remained quite high (see Table 2). There was a slight decline in that ratio in Latin America in the 1980s and 1990s while the decline was more substantial for SSA. The ratio increased for SAS from very low levels, and even in EAP, where it was already very high.

Growth picked up in recent years in all the developing regions (see Table 1). Furthermore, investment revived, though modestly in the LAC and SSA regions, which raised hopes that the higher growth rates would be sustained. Such hopes were supported by the improvement in the balance of payments (BOP) figures because of rising remittances ${ }^{7}$ and improved export performance. ${ }^{8}$

\section{International transactions}

\section{Capital flows}

Developing countries, after lagging behind the developed countries in eliminating capital controls, have liberalised inflows of capital in recent years. Consequently, private flows have grown rapidly and become much more important than aid. ${ }^{9}$ Within private capital flows, equity flows, particularly foreign direct investment (FDI), are more important than debt-creating flows. ${ }^{10}$ Increasingly the capital inflows, more than the current account deficits, are financing reserve accumulation and capital outflows, mainly as foreign investment or debt repayment so as not to raise growth rates.

Table 2. Gross fixed capital formation (\% of GDP)

\begin{tabular}{lccccc}
\hline Region & $1965-1973$ & $1974-1982$ & $1983-1990$ & $1991-2000$ & $2000-2007$ \\
\hline World & 23.6 & 23.9 & 22.5 & 22.0 & 21.1 \\
High income & 24.4 & 23.8 & 22.3 & 21.4 & 20.4 \\
LAC & 20.1 & 22.7 & 19.2 & 19.3 & 20.4 \\
SSA & 21.8 & 24.0 & 18.5 & 17.2 & 19.7 \\
MNA & & 26.5 & 23.3 & 21.7 & 24.1 \\
SAS & 14.8 & 17.8 & 20.0 & 21.4 & 27.4 \\
EAP & & 28.4 & 28.5 & 32.6 & 34.7 \\
\hline
\end{tabular}

Notes: EAP, East Asia and the Pacific (EAP); SAS, South Asia; LAC, Latin America and the Caribbean; SSA, sub-Sahara Africa; and MNA, Middle East and North Africa.

Source: World Bank World Developments Indicators 2004. Washington, DC: World Bank; World Bank World Developments Indicators 2007. Washington, DC: World Bank; World Bank World Developments Indicators 2009. Washington, DC: World Bank. 
South Asia has consistently run large deficits on the external balance of goods and services, whereas the Latin America and SSA regions have had surpluses since the 1980s, reflecting their inability to attract enough capital and the consequent need to run surpluses to repay their external debt or to build up reserves.

\section{Trade in goods and services}

Barriers to trade have been continuously lowered in post war years through multilateral trade negotiations (MTNs). Developing countries, after maintaining high tariff rates until the 1970 s as they pursued import substituting industrialisation policies, have reduced tariffs drastically since then. The average tariff in most developing countries is currently about $10 \%$, though tariffs in African and South Asian countries are somewhat higher.

Trade liberalisation helped raise the export-to-GDP ratio in all regions during the past four decades. The ratio increased dramatically in East Asia. The ratio stagnated in the 1980s and 1990s in SSA, where it was already very high and in Latin America, but has increased in the new century. The ratio has increased in South Asia mainly since the 1990s, but this increase began from very low levels so the ratio remains smaller than in other regions.

Developing countries have steadily increased their share of world exports from $20 \%$ in the pre-Second World War period, to 28\% in 1998-2000; their share in exports of manufactures has risen particularly sharply. The share of exports from all developing country regions destined for least developed countries (LDC) markets has increased from about $24 \%$ in 1955 to $30 \%$ in $2007^{11}$ reflecting increasing incomes and demand.

World trade in services has been especially dynamic, growing at $16 \%$ a year during 1995-2007. Asian countries did well; the share of other developing country regions in world exports of commercial services has declined. The performance of countries in sub-Saharan Africa in exports of commercial services has been particularly poor.

\section{Economic performance of the IBSA countries}

\section{Macroeconomic performance}

The economies of India, Brazil and South Africa are ranked as the $11^{\text {th }}, 10^{\text {th }}$ and $33^{\text {rd }}$ largest, respectively, among over 200 countries and territories (see Table 3 ). The economies of India and Brazil are roughly the same size at around \$1 trillion gross national income (GNI) each, while South Africa's economy is far smaller at \$274 billion GNI. $^{12}$

The IBSA economies are large partly because of their populations: India is the second most populated country in the world with a population of over 1.1 billion and Brazil the fifth most populated with 192 million. South Africa's population is ranked $25^{\text {th }}$ in the world at only 48 million. In terms of per capita income, individuals in Brazil and South Africa are more than five times as wealthy as their counterparts in India. India ranks very low, $159^{\text {th }}$, with an annual per capita income of US\$ 950.

Per capita incomes in South Africa declined in the last two decades of the $20^{\text {th }}$ century before growing by about $2 \%$ a year between 2000 and 2007. Per capita income in Brazil after declining in the 1980s has grown at almost $2 \%$ a year since 
Table 3. Size of the economies of IBSA and their regions, 2007

\begin{tabular}{lrrrcc}
\hline Region & $\begin{array}{c}\text { Population } \\
\text { (millions) }\end{array}$ & \multicolumn{1}{c}{$\begin{array}{c}\text { GNI } \\
(\mathbf{S b})\end{array}$} & $\begin{array}{c}\text { GNI per } \\
\text { capita }(\$)\end{array}$ & $\begin{array}{c}\text { GDP growth } \\
\text { rate 1990-2000 }\end{array}$ & $\begin{array}{c}\text { GDP growth } \\
\text { rate 2000-2007 }\end{array}$ \\
\hline World & 6,610 & 52,850 & 7,995 & 2.9 & 3.2 \\
LAC & 561 & 3,252 & 5,801 & 3.2 & 3.6 \\
Brazil & 192 & 1,122 & 5,860 & 2.7 & 3.3 \\
SSA & 800 & 761 & 951 & 2.5 & 5.1 \\
South Africa & 48 & 274 & 5,720 & 2.1 & 4.3 \\
SAS & 1,522 & 1,339 & 880 & 5.5 & 7.3 \\
India & 1,125 & 1,071 & 950 & 5.9 & 7.8 \\
\hline
\end{tabular}

Notes: SAS, South Asia; SSA, sub-Sahara Africa; GNI, gross national income.

Source: World Bank World Developments Indicators 2009. Washington, DC: World Bank.

then. The Indian economy grew considerably faster - almost twice the world rate. Growth rates of both the manufacturing and services sectors have been much higher in India than in either Brazil or South Africa. In South Africa agricultural growth also has lagged. ${ }^{13}$

However, the growth rates of these three economies accelerated in the new century, with India growing particularly fast.

The large differences in growth rates are because of differences in ICORs and not in investment ratios. Investment ratios were lowest in South Africa at $16-17 \%$ of GDP, ${ }^{14}$ about $3-4 \%$ lower than in Brazil and about 7\% lower than in India. But the South African investment ratio has increased in recent years and is now higher than in Brazil. The investment ratio has further accelerated in India so that it is almost double that in the other two countries. However, the ICOR in both Brazil at 0.15 and South Africa at 0.10 is considerably lower than in India, which is at 0.24 . Obviously, Brazil and South Africa will require improved capital efficiency or a much higher investment ratio to raise their growth rates.

India is a much more agriculturally focused economy than Brazil and South Africa. Agriculture's share in India's GDP was 23\% in 2002 compared to $6 \%$ and $4 \%$ respectively for Brazil and South Africa. ${ }^{15}$ Because of a decline in manufacturing's share of GDP in Brazil and South Africa in the 1990s, the shares of manufacturing in the three countries are much more similar today than in the past. India, however, has a much smaller share of services in GDP than the other two countries.

\section{IBSA capital flows}

Brazil's debt exceeds $\$ 190$ billion - roughly 20\% of its GDP - while the value of South Africa's debt is around $\$ 35$ billion, which is $12 \%$ of GDP, and India's is around $\$ 150$ billion, or less than $15 \%$ of GDP. ${ }^{16}$ Private capital flows to Brazil, India and South Africa were \$18.6, \$5 and \$5.6 billion, respectively, in 1995 and increased to $\$ 80, \$ 83.9$ and $\$ 19.4$ billion, respectively, in 2007 .

South Africa has fallen behind the other two countries in attracting private capital, and private flows to India have surged. But the three countries have somewhat similar patterns of capital inflows, with bonds and bank lending accounting for 25 to $30 \%$ of the flows and the rest being FDI and portfolio capital. FDI inflows are widely disparate, with Brazil exceeding $\$ 35$ billion, India just above $\$ 20$ billion and South Africa recording less than \$2 billion in 2007. Inflows to Brazil 
will increase further if the new-found oil reserves off the Brazilian coast are developed. ${ }^{17}$

\section{Balance of payments}

The BOP positions of the three countries are very different. Brazil has had an increasing surplus on merchandise trade, and as the deficit on services decreased, the current account moved into surplus (see Table 4). The current account surpluses that South Africa ran in the 1990s have gradually eroded and currently the country has a current account deficit, as does India.

All three countries have been accumulating reserves. India's foreign exchange reserves were to the value of over 10 months of imports in 2007. However, South Africa's reserves currently are still less than three months of imports.

\section{IBSA trade in goods and services}

In terms of total trade, once again Brazil and India are on a par, with trade of about $\$ 130$ billion, while South Africa's total trade barely exceeds $\$ 70$ billion. The share of exports in GDP has increased substantially in all three economies, as it has in the world economy and in their regions. However, South Africa has a much higher export to GDP ratio than the other two states. The large and increasing share of manufactures in the export baskets of the three countries reflects the increasing importance of export production for the sector. ${ }^{18}$ Consequently, the declining or stagnant share of manufacturing in GDP in the three countries does not bode well for future exports.

Despite services being a smaller share of GDP in India than in Brazil and South Africa, India has fared better in exports of services, particularly information technology (IT) related commercial services. Over the last decade, India's share of world exports of commercial services has more than quadrupled and service exports as a share of total exports has increased from $18 \%$ to almost $40 \%$. Brazil's share in world exports of services and the share of services exports in its total exports have both increased, as well. But in the case of South Africa, whereas the share of service exports in total exports has increased, its share of world exports of services has not kept pace, and actually decreased during this period.

Brazil and India are very vulnerable to terms of trade shocks as they are heavily dependent on imports of fuels. But this should change in the future with the discovery of oil in both Brazil and India. This improves their prospects; however, much depends on how soon the production of significant quantities of oil can start. ${ }^{19}$

Table 4. Trade and current account balance, 1990 and 2007 ( $\%$ of GDP)

\begin{tabular}{lcccc}
\hline & $\begin{array}{c}\text { Trade balance } \\
(1990)\end{array}$ & $\begin{array}{c}\text { Trade balance } \\
(2007)\end{array}$ & $\begin{array}{c}\text { Current account } \\
\text { balance (1990) }\end{array}$ & $\begin{array}{c}\text { Current account } \\
\text { balance (2007) }\end{array}$ \\
\hline Brazil & 1.5 & 2.6 & -0.8 & 2.0 \\
South Africa & 6.0 & -7.5 & 1.9 & -2.0 \\
India & -2.1 & -6.0 & -2.2 & -2.0 \\
\hline
\end{tabular}

Source: World Bank World Developments Indicators 2009. Washington, DC: World Bank. 
South Africa too is becoming more vulnerable as it has now become a net importer of fuels. Brazil and South Africa are also more vulnerable to the long term decline in prices of primary commodities, which are important elements of their export baskets.

In brief, while their economic performances have improved, the BOP position of each is fragile as the supply of exports of manufacturing is relatively stagnant. Prospects for India are better due to exports of commercial services, however, all three economies are vulnerable to increases in the price of oil, and Brazil and South Africa are especially subject to fluctuations in commodity prices.

\section{IBSA and the MDGs: social progress indicators}

The democratically elected governments of the IBSA countries face the formidable task of ensuring a widespread distribution of the benefits of growth, a challenge which is particularly daunting for governments where there is insufficient economic growth. The following discusses the magnitude of the challenges facing the IBSA countries by analysing their progress in achieving the UN's Millennium Development Goals. Brazil fares considerably better than India and South Africa on the Human Development Index, where it occupies $63^{\text {rd }}$ position out of 177 countries, while South Africa and India occupy $120^{\text {th }}$ and $127^{\text {th }}$ ranks, respectively. ${ }^{20}$

These relative rankings are reflected in the achievements regarding the individual indicators. We present below the main indicators of the major MDGs (see Table 5). ${ }^{21}$

The first MDG is to halve the extent of hunger and poverty between 1990 and 2015. The problems of hunger and poverty are more serious in SAS and SA than in LAC. The extent of poverty, defined as the proportion of people whose income is less than $\$ 1$ a day, was only 11.3 in LAC in 1960 , but 44.6 in SSA, and 41.3 in SAS. ${ }^{22}$ The extent of poverty declined in South Asia during the 1980s and 1990s to reach 31.1 in 2001. The extent of poverty increased in LAC and SSA in the 1980s. The situation then turned round in LAC, as the poverty ratio declined to 9.5 in 2001 . The poverty ratio continued to increase in SSA, however, and was 46.5 in 2001.

The countries' poverty indices are collectively troubling. The poverty ratio in Brazil, 8.2, is considerably lower than in India, 34.7 and in South Africa, where it had increased in the 1990 s to reach 26 in $2000 .{ }^{23}$ Brazil is within reach of meeting the MDG goal of halving its poverty ratio by 2015 . In India the situation is more complex. Whereas the World Bank data using the international poverty line shows some progress - but not enough to meet the MDG goal - the use of the national poverty line suggests that the goal will be met as the poverty ratio declined from $36 \%$ in 1993-1994 to $27.5 \%$ in 2004-2005. The task of further reducing the poverty ratio in Brazil and reducing poverty in South Africa is complicated by the unequal income distribution. The more equal income distribution in India means that growth itself will reduce poverty considerably.

The Gini coefficient measuring income inequality (were less is better) was 59.1 in Brazil and 59.3 in South Africa, whereas it was 32.5 in India. The poorest decile receives only $0.5 \%$ and $0.7 \%$ of the country's income in Brazil and South Africa, respectively, and the next poorest decile earns $1.5 \%$ and $1.3 \%$, respectively, of the country's income. The second poorest $20 \%$ earn $5.7 \%$ of income in Brazil and $4.3 \%$ of income in South Africa. In contrast, the poorest decile in India earns 3.9\% of the income and the next poorest decile earns $5 \%$ of income and the second poorest $20 \%$ earn $12.3 \%$ of income. Because the poorest decile in India has a higher share 
Table 5. Progress towards achieving MDG's in IBSA regions and countries

\begin{tabular}{lccc}
\hline & 1990 & 2000 & 2005 \\
\hline Poverty ratio* & & & 8 \\
LAC & 11 & 11 & 8 \\
Brazil Aia & 15 & 11 & 40 \\
South Asia & 52 & 44 & 42 \\
India & 54 & 49 & 42 \\
SSA & 58 & 58 & \\
South Africa & & 26 & \\
\hline
\end{tabular}

Primary school enrolment: number of children enrolled in primary school as percentage of children of age to go to primary school.

\begin{tabular}{lrrr}
\hline & 1990 & 2000 & 2005 \\
\hline Primary school enrolment & & 94 & 95 \\
LAC & 93 & 108 & 106 \\
Brazil & 80 & 89 \\
South Asia & & 72 & 94 \\
India & & 60 & 71 \\
SSA & 91 & 94 & 93 \\
South Africa & & \\
\hline
\end{tabular}

Female-male enrolment ratio: number of girls enrolled in primary school as percentage of boys enrolled in primary school

\begin{tabular}{lccc}
\hline & 1990 & 2000 & 2005 \\
\hline Female-male enrolment ratio & & & \\
LAC & 99 & 97 & 97 \\
Brazil & & 94 & 94 \\
South Asia & 75 & 83 & 96 \\
India & 74 & 85 & 88 \\
SSA & 84 & 95 & 96 \\
South Africa & 99 &
\end{tabular}

Child mortality rate: deaths of children under age 5 years per 1000 live births

\begin{tabular}{lrrr}
\hline & 1990 & 2000 & 2005 \\
\hline Child mortality rate & & & \\
LAC & 52 & 34 & 27 \\
Brazil & 56 & 34 & 26 \\
South Asia & 125 & 97 & 81 \\
India & 118 & 93 & 77 \\
SSA & 181 & 160 & 65 \\
South Africa & 62 & 77 & \\
\hline
\end{tabular}




\begin{tabular}{|c|c|c|c|}
\hline & 1990 & 2000 & 2005 \\
\hline \multicolumn{4}{|c|}{ Maternal mortality rate: deaths per 100,000 live births } \\
\hline \multicolumn{4}{|c|}{ Maternal mortality rate } \\
\hline LAC & 140 & 110 & 91 \\
\hline Brazil & 120 & 79 & 64 \\
\hline South Asia & 610 & 430 & 330 \\
\hline India & 570 & 390 & 280 \\
\hline SSA & 870 & 800 & 710 \\
\hline South Africa & 230 & 380 & 490 \\
\hline
\end{tabular}

Notes: *The poverty benchmark used by The World Bank has been changed form $\$ 1.00$ a day to $\$ 1.25$ a day. The revision followed new data and that from a larger number of countries. SSA, sub-Sahara Africa; LAC, Latin America and the Caribbean.

Source: The World Bank Millennium Development Goals Website, Global Data Monitoring Information System < http://ddp-ext.worldbank.org/ext/GMIS/home.do?siteId=2 > .

of income, their average per capita income is more than that of the poorest decile in Brazil and South Africa, despite India's much lower aggregate per capita income. At India's current rate of growth of per capita income, most of those in the $2^{\text {nd }}$ to $4^{\text {th }}$ deciles should be able to climb out of poverty, and the poverty ratio may fall to as low as $10-15 \%$, in which case India could meet the MDG target comfortably.

The prevalence of hunger mirrors that of poverty. The percentage of the population that is hungry has shown a steady decline in SAS and LAC during the 1990s, whereas the percentage has remained constant at a much higher level in SSA, though it began to decline in the second half of the 1990s. Malnourishment of children, partly responsible for high rates of child mortality, has been specifically targeted. Rates of child malnourishment are low in LAC, as only about 5\% of children under the age of five are malnourished. ${ }^{24}$ Malnourishment has declined substantially between 1990 and the early years of the new century, by $33 \%$ and $25 \%$ in East Asia and South Asia, respectively. In this area, progress has been substantial in those SSA countries for which data is available. However, the extent of malnutrition is still large, as $41 \%$ and $27 \%$ of children under five are malnourished in SAS and SSA, respectively.

Malnourishment and inadequate facilities are major factors in the poor health of vulnerable segments of the population. Maternal mortality is particularly high in India and South Africa. But whereas it has increased in South Africa to 490 per 100,000 live births, it had decreased in India to 280 by 2005. India's target for 2015 is 143 and, if the current rate of progress continues, the target should be met. The situation is much better in Brazil where the maternal mortality rate is 64 per 100,000 live births. But after rapid decline in the 1990s the rate of decline slowed down significantly during the period 2000-2005 and more attention would need to be paid to the health of pregnant women if the target of 30 is to be achieved. Similarly child mortality rates are much lower in Brazil at 26 per 1000 births in 2005, having fallen by nearly $60 \%$ between 1990 and 2005. Child mortality, at 77 and 65 per 1000 births, are much higher in India and South Africa, respectively. Furthermore, they have increased in South Africa and have fallen by only about a third in India. Only Brazil seems to be on target to reduce child mortality by two-thirds. 
The next MDG under scrutiny relates to education. Attaining universal primary education and eliminating gender inequality at all levels of education by 2015 are the goals. While all three countries are likely to meet or come close to meeting these goals, serious problems still remain about the quality of education. Less than $60 \%$ of those entering primary education complete grade five in India. The situation is better in South Africa and Brazil, where the problem is more an issue of repeaters - $10 \%$ in South Africa and more than $20 \%$ in Brazil. In India, those who fail drop out rather than repeat. The low completion rates in India partly account for low literacy levels in India - about $60 \%$ for all adults and $70 \%$ of those aged between 15-24 years. In Brazil and South Africa, the overall adult literacy rate is over $80 \%$ and that of the youth is over $90 \%$. Brazil and South Africa have achieved gender equality in primary and secondary enrolments, whereas in India the ratio of female to male enrolment was only $79 \%$ over the past decade.

In brief, Brazil not only started with better social indicators than India or South Africa but has also made more significant strides and is likely to meet many of the MDGs. This could be attributable to several factors, including strong economic performance in the past decade and social programmes such as 'bolsa de familia' which is described in greater detail below. India may meet some of the MDGs but is likely to fall short in a number of them, particularly in the area of health. South Africa has had the most severe problems in progressing towards achieving the MDGs and in many areas there has been backward movement. As discussed below, civil society is least involved with social programs in South Africa and this may account for the poor performance in this area.

\section{The social development programmes of India, South Africa and Brazil}

What steps has each of the IBSA countries made toward social development to address the needs of society outlined above? A brief survey, based in the national context of each, is instructive.

\section{India: social development by special programme}

The elimination of poverty and reduction of income inequalities are major issues taken up by virtually every political party in India. Op-ed pages of major newspapers are replete with articles discussing policies needed to achieve social justice. India, however, remains very low on the Human Development Index (HDI), despite the country's rapid economic growth. ${ }^{25}$ This low rank reflects an odd contradiction at the heart of policy making in India: special programmes, some of which are discussed below, cater to the needs of the poor, while general policies neglect the services that would provide them with the skills and opportunities needed to better themselves.

The drive to eliminate poverty is, in part, a legacy of India's 'freedom movement' through which generations of Indians pressed for Indian independence from British rule, beginning in the mid-1800s. The charge that the British neglected the welfare of the common man was a factor in motivating participation in the freedom movement and in a broader mobilisation of society. ${ }^{26}$ It was in that context that Mahatma Gandhi enunciated his famous concerns about the poor. ${ }^{27}$ This same concern led the government to establish a high level committee at the end of the 1950 s, 10 years into independence, to analyse why poverty was not decreasing. ${ }^{28} \mathrm{~A}$ 
major impediment in reducing poverty was, in fact, the development strategy adopted by the Indian government. This strategy concentrated investment in the capital goods sector, as some models of growth had concluded this would lead to faster growth. ${ }^{29}$ But far too few jobs were created in the capital intensive capital goods sector. Next, policy sought to induce job creation in the labour intensive handicrafts sector. But again this strategy did not work, ${ }^{30}$ as the handicrafts sector failed to be competitive. ${ }^{31}$ Not until the 1980s did economic policy begin to engender the sort of growth that would make a material difference in the lives of many Indians. Even now, poverty remains a dominant feature in too many Indian communities.

\section{'Garibi Hatao'}

Poverty concerns during the first few decades after independence were poorly translated into policy, and, even more importantly, stated policies were not always implemented. The clearest example is provided by the policies regarding land reform. The ruling Congress Party passed resolutions in the 1950s and early 1960s calling for extensive land reform, ${ }^{32}$ and the planning commission based its strategy and calculations on such reform. However, the local landed elites on which the Party depended for votes prevented the implementation of the reforms. ${ }^{33}$ Redistribution of assets was not considered a serious option as its impact was believed to be limited; the reigning logic was that economic growth was the best way to tackle poverty.

This reasoning was made explicit in the preparatory work on India's Fifth Plan, which sought to realise the Congress Party's slogan of 'Garibi Hatao', namely, remove poverty, which had been instrumental in its landslide electoral victory. After a detailed analysis of various options, including redistribution, ${ }^{34}$ the Planning Commission concluded that even if the poor got all the incremental income from growth there would be only a limited impact on the overall extent of poverty. The economy needed to grow 7\% annually, at least, for a significant reduction in poverty to occur. Subsequent experience has tended to support this analysis. The high rates of growth that have been achieved since the early 1980s, supplemented by special programmes, have caused a significant reduction in poverty. ${ }^{35}$

This paradox in which, on the one hand, the government supplemented the effects of growth by special programmes, while on the other hand it was neglecting health and education services, remains today. There has been no increase in the share of these expenditures as a percentage of either total government expenditures or of GDP. This has reduced the ability of the poor to find better paying jobs and reduced the extent of human capital formation, which has limited productivity improvement and GDP growth.

\section{India's NREGS}

While the government has neglected expenditures on health and education that would have benefited the poorer sections of the population, it has instituted a number of special programs to assist the poor. These programmes are in response to pressure from various civil society organisations and at the same time earn the government electoral benefits as it can claim that it is trying to help the poor. ${ }^{36}$ One such scheme is the National Rural Employment Guarantee Scheme (NREGS), which provides employment for 100 days at the minimum wage to one member of any family in which no member has employment. The programme began in February 
2006 in the 200 least developed areas of India and, under pressure from civil society, has since been extended to the entire country. Almost 45 million people were provided employment under the scheme in 2008-2009. This is beginning to have a significant effect in the rural areas. ${ }^{37}$ Almost $50 \%$ of the person-days created under the programme went to disadvantaged groups. In addition there are programs to assist self-employed people in the rural and urban areas with credit and subsidies to create assets which would bring them above the poverty line. ${ }^{38}$

\section{Sarva Shiksha Abhiyan}

The $86^{\text {th }}$ amendment to India's constitution in 2002 made free and compulsory education for children between the ages of six and 14 a fundamental right. But the implementation of this right has been delayed. Currently, the main programme for improving access to elementary education for all children in India is the Sarva Shiksha Abhiyan programme. This programme provides for construction of new schools, upgrades to existing buildings and other facilities and provision of free textbooks. First launched in 2001-2002, it is a partnership between the central and state governments, which seeks to improve the performance of the school system through a community-owned approach. There are additional special programmes, such as the National Programme for Education of Girls at Elementary Education, to improve access of girls to school, including providing residential accommodation for girls belonging predominantly to the minorities and other disadvantaged sectors of the population. ${ }^{39}$ A major effort to encourage school attendance is the mid-day meals programme. During 2008-2009, 117 million children in grades one to five and 35 million in grades six to eight were covered by the meal scheme. With increased numbers of students enrolling in primary schools and graduating, a Secondary School Programme was launched in 2008-2009 to improve access to secondary education.

Delivery of health services is also being improved through the National Rural Health Mission (NRHM). Begun in 2005, it is supposed to deal with the major health challenges, such as malaria, blindness, and iodine deficiency, and includes elements of hygiene, nutrition, provision of safe drinking water and improved sanitation facilities. Five years into its mission, the NRHM has received mixed reviews. For instance, while both maternal and infant mortality rates have come down, the undernourishment in the country has remained almost unchanged. In India, about $46 \%$ of children show stunted growth. ${ }^{40}$

One of the major problems with social programmes has been unsatisfactory implementation, but also the lack of access to information. ${ }^{41}$ To assist civil society and the poor in overcoming these obstacles, another piece of legislation was introduced to improve service delivery, in the form of the Right to Information (RTI) Act. Under the RTI, an individual can ask for information about the programmes and inquire about rejected requests. The evidence suggests that the poor are using the Act to get information, and this can be used to point out shortcomings in the implementation of the programme. ${ }^{42}$

The improved offering of social programmes, and their implementation, has largely been brought about by the involvement of civil society and NGOs in India. The NREGS, the $86^{\text {th }}$ amendment, and the RTI were all pushed vigorously by civil society. These measures were adopted despite government opposition because civil society groups were able to convince the president of the main governing party, the 
Congress, of the need, and the long term advantages. The fact of India's phenomenal economic growth noted earlier has, no doubt, been a factor as well.

\section{Brazil: marked progress in socio-economic development}

Brazil had long been considered a country that failed to meet its enormous potential and the expectations of the international community, created in the 'miracle years' of the 1960s and 1970s when Brazil was one of the fastest growing economies in the world and the greatest developing world prospect for the future. ${ }^{43}$ Throughout the 1980 s, Brazil achieved only mediocre growth rates ${ }^{44}$ and inconsistent development across the country. ${ }^{45}$ Recent indicators, the global recession notwithstanding, are, however, promising. By 2009, the Brazilian economy had resumed growth and is producing some of the best results in the country's recent history, including high growth rates, massive inflows of foreign investment and a growth in exports across all sectors of the economy. After posting growth rates of 5.7\% in 2007 and $5.1 \%$ in 2008 , Brazil's GDP dropped $0.2 \%$ in 2009 , which was laudable in view of worldwide trends after the financial crisis of late 2008. The Lula government acted to minimise the impact of the global financial and economic crisis with an injection of more than $\$ 100$ billion into the economy to provide additional liquidity, as well as tax and interest rates cuts, to good effect. Brazil emerged from the global financial crisis in 2009 and economic growth is estimated to reach $7.1 \%$ in 2010. A more sustainable growth level, in the range of $4.5 \%$, is predicted for $2011 .^{46}$

But the harsh living conditions and day-to-day reality for the poor majority is still unacceptable in a country with such vast resources. More than 40 million Brazilians live on less than $\$ 2$ a day. ${ }^{47}$ The juxtaposition of the 'favelas' or slums and the shiny high rise apartments and business centres in major cities such as Sao Paolo and Rio de Janeiro is testament to the continuing inequality.

This may change. Brazil finally is achieving relatively impressive results in socioeconomic and human development - most notably in poverty alleviation, a declining HIV infection rate, and improved access to education. ${ }^{48}$ This improvement in traditional weak spots in Brazil's social agenda can be attributed to a new approach to development that blends coherent liberal economic reforms effectively. These include market liberalisation, privatisation, an effective investment regime and fiscal austerity which have delivered growth, and targeted social policies that have proven most effective in reaching the poor.

This somewhat unique combination has required considerable commitment, leadership and creativity, and may be instructive for other countries with similar socio-economic challenges - including India and South Africa. Already, aspects of Brazil's programmes have been implemented in New York and Cairo. ${ }^{49}$

\section{Brazil's zero hunger programme}

Shortly after his election in October 2003, President Luiz Inacio 'Lula' da Silva launched an ambitious programme to address poverty under the title 'Zero Hunger' ${ }^{50}$ This programme, and especially the flagship component 'Bolsa Familia', emphasises the reduction of hunger and malnutrition through a novel and integrated approach that incorporates other social priorities from education to a grounded family structure through a focused and simple methodology of conditional cash transfers or effective non-labour income. 
Some critics have called Zero Hunger just another political manoeuvre by the left-leaning Lula administration that further cheapened the plight of the country's masses. Supporters of the programme, on the other hand, describe this broad based and highly integrated cash transfer system as a social inclusion programme that helps generate income while improving productivity and encouraging education, which helps redeem self-esteem and promotes citizenship.

\section{Bolsa Familia}

Based on the UN Millennium Development Goals, Zero Hunger's short-term goal was to guarantee at least one decent meal a day to every family in Brazil by 2006, and a longer term goal of three meals a day by the end of $2010 .^{51}$ By the time of Lula's second presidential election in 2006, social spending in Brazil had tripled to $\$ 10$ billion.

Programmes like Bolsa Familia have now been credited with dramatic declines in inequality along with substantial poverty cuts. By 2009 Bolsa Familia - the world's largest conditional cash transfer programme - was reaching close to 11.5 million families and the Lula administration was on track to achieving its goal of three meals a day to every Brazilian. ${ }^{52}$

There are obvious challenges in delivering such a programme in large, diverse countries that have both rural and urban-based poverty, as in Brazil, South Africa and India. It is for this reason that Bolsa Familia in Brazil initiated an approach that focused in particular on poor families - not just poor districts - in the poorest north-eastern region and among the non-metropolitan population. While the funding originates from Brazil's federal government, it is the sub-national and municipal governments that, with the help of community leaders and nongovernmental organisations (NGOs), identify specific families most in need, and then distribute the grants comprehensively and in a timely fashion. The funds are distributed monthly via deposits into debit card accounts, directly to the mothers of families that are living below a certain level of income, based on the number of children in the family. This conditional cash transfer is withheld if children's school attendance is not adequate, or for failure to comply with public child vaccination programmes, among other conditions. ${ }^{53}$

Civil society groups played an important part in the rolling out of the programme. They have been involved in not only the targeting of the neediest families, but are also active in the various community kitchens, community gardens and more direct linkages with the farmers. This approach of active shared responsibility between local government and civil society is referred to, in Brazil, as 'shared management'. It has proven most effective in addressing widespread hunger and, as some believe, even demonstrates a new frontier of democracy in large developing countries whereby the active involvement of citizens in policy implementation can help ensure real and quick results.

While results of Bolsa Familia are not conclusive due to possible data irregularities and, some say, the partisan nature of the programme, recent studies do indicate that poverty has reduced markedly since 2003, with the number of poor and indigent in Brazil dropping from 15.4 million to 11.3 million in 2008 - a $21 \%$ drop in just six years. ${ }^{54}$ 
Complementing economic progress with social policies

Some analysts and politicians argue that the reduction in poverty levels in Brazil can be attributed to economic growth based on liberal reforms and the resource boom in recent years. While this group acknowledges a steady decline in poverty and inequality they tend to praise Lula for his commitment toward economic stability and openness through accepted orthodox policies and often dismiss the impact his social policies have had across the country.

Economic growth and seemingly endless natural resource wealth (and potential) in Brazil have provided resources and sufficient flexibility around socio-economic development in Brazil. Without such economic support, Lula's ambitious social programmes would certainly not have been possible or, at least as effective. But these very same programmes also ultimately make an important contribution to the economic prosperity of the country and help to legitimise the government and its policies in the eyes of the people. Besides the short-term stimulation that the cash transfers have supplied - resulting in declining unemployment and increased business returns ${ }^{55}$ - their greatest contribution is in the productive input they provide in the long-term, which various studies have proven follows from improved education, healthcare and poverty alleviation.

In short, the succession and sequencing of tough liberal reforms through the 1990s, which helped place Brazil firmly on a positive economic growth trajectory, followed by effective social programmes that were managed through decentralised implementation are behind the positive results in Brazil. It is clear that in such societies and under such challenging circumstances - highly partisan with immense political and economic complexity - no single social programme will address the broad range of developmental requirements adequately. This can only be done through the combination of public policies, economic imperatives and transfer programmes illustrated above.

Clearly, the true strength of Zero Hunger - and, in particular Bolsa Familia lies in the social and geographical extent of the programmes (from basic unconditional transfers to extremely poor families, to those tightly linked to basic education and family-building conditionalities) together with the effective implementation that utilises various layers of government and civil society.

The promise of increased government revenues through the development of Brazil's oil fields, as well as a transition in national leadership from Lula, who has served his two consecutive terms in office allowed by the constitution, will introduce new dynamics into the Brazilian policy landscape, no doubt. Many believe that with economic growth, and a candidate from Lula's own party in office, ${ }^{56}$ the upward trajectory of social development in Brazil can be maintained. This, however, is the great challenge in Brazil: as the expansion of these programmes and results become more expensive, fiscal constraints may require less dependency on public transfers, while the government must maintain political legitimacy and economic balance. ${ }^{57}$

\section{South Africa: tackling inequality post 1994}

South Africa is Africa's largest and most sophisticated free-market economy with a GDP of $\$ 277$ billion. South Africa accounts for approximately $40 \%$ of all industrial output, $25 \%$ of gross domestic product, over half of generated electricity and $45 \%$ of 
mineral production in Africa although having only 3\% of the continent's surface area and roughly $4.7 \%$ of its population. ${ }^{58}$

Today, the country has a two-tiered economy, a legacy of apartheid: ${ }^{59}$ one rivalling developed countries that caters mainly to the elite comprised of most white South Africans, who make up roughly $9.6 \%$ of the population, as well as a small rising affluent black (including Indian, Asian and 'coloured') population, and the other catering for the vast majority of black South Africans. ${ }^{60}$ To demonstrate the disparity, the elite economy of South Africa would be ranked $24^{\text {th }}$ in the world, on a par with the rich countries, while the second tier economy of South Africa would be ranked $123^{\text {rd }}$ in the world, alongside the poorest. ${ }^{61}$ Almost half of the total population is classified as poor using a national poverty line, ${ }^{62}$ with more than $60 \%$ of blacks considered poor compared to approximately $1 \%$ of the white population. ${ }^{63}$ The resulting deep-seated frustration of the vast majority of the population creates an inherently unstable political situation. ${ }^{64}$

\section{South Africa's poverty alleviation projects and social security}

The South African Department of Social Development has the primary responsibility to tackle poverty and inequality in the country. Starting in 1997, it developed programmes targeted to the country's youth, women and people with disabilities to provide start-up capital and on-going support for income generating small projects, basic skills development and education in technical areas. More than R640 million or $€ 67.4$ million was allocated for these projects between 1997 and $2004 .^{65}$

However, institutional care and statutory services continued to make up the bulk of welfare work (albeit now provided on a non-racial basis) with minimal preventive services and development. ${ }^{66}$ Furthermore, the Department of Social Development was more than once found not to have been able to spend its allocation of the Poverty Relief Fund appropriately. A lack of effective administrative systems and process and lack of capacity have often been blamed. ${ }^{67}$ It became evident that these projects were carried out by social workers who did not have experience in community development initiatives, though recent research has indicated that this is changing slowly. ${ }^{68}$

Some successful poverty alleviation projects, such as a number of incomegenerating projects in KwaZulu-Natal, have had a positive impact on the lives of the project participants. ${ }^{69}$ Apart from increasing incomes by up to R1000 (approximately $€ 105)$ per month per project, participating individuals reported positive spin-offs including increased school attendance by their children and the economic empowerment of women involved with these projects. ${ }^{70}$ Nevertheless, there is a general sense that the projects have not significantly contributed to poverty reduction and long term employment generation.

At the same time, the government has been involved in an on-going debate over the purpose and scope of South Africa's social security system, which consists of both in-kind and cash benefits. ${ }^{71}$ In-kind transfers, expanded by the African National Congress (ANC)-led government since the end of apartheid in 1994, are aimed at the most impoverished and destitute in South Africa's population. ${ }^{72}$ Benefits include school-feeding schemes; free water; free basic medical care to children under the age of six; food parcels and clothing for households with terminally ill family members and for child-headed households; housing; and public transport subsidies. 
In comparison with other developing countries, the South African social security system is quite well organised. Critics, however, have questioned both its effectiveness and efficiency to tackle poverty and inequality in the country. The country's most impoverished citizens have often not received cash transfers, as children in childheaded households often do not qualify for grants which must be paid to adult holders of a South African identification document. ${ }^{73}$ Adults have had to struggle in bearing the cost associated with applying for these grants, such as obtaining an identity document. While it is assumed that these grants will pay dividends in the long term, their policy efficiency in the medium terms is being compromised due to such challenges. ${ }^{74}$

\section{From Mandela's RDP to Mbeki's GEAR}

Concomitant with these long-standing programmes, Nelson Mandela's ANC government introduced in 1994, after the demise of apartheid, the Reconstruction and Development Programme (RDP) which sought to address the legacies of apartheid, and had a dual function. As a policy framework, its agenda allowed increased social spending and also influenced the government's decision to seek donor assistance. Meanwhile, this programme allowed for the financing of high profile 'presidential projects', such as a school feeding initiative, free medical care for children below the age of six and pregnant mothers, as well as public works projects for unemployed youths. RDP resulted in the erection of new houses, improved access to water and electricity, improved health facilities and substantial expenditures on poverty relief. ${ }^{75}$ A 1995 study by the Community Agency for Social Enquiry (CASE) had found that water was available from an indoor tap in only $20 \%$ of black households. There was no toilet of any kind in nearly $20 \%$ of homes and nearly $60 \%$ had no electricity. ${ }^{76}$

RDP failed to make a significant dent in poverty and inequality in South Africa for various reasons. Real GDP growth, at approximately $2.3 \%$, was much lower than envisaged and far short of the $6 \%$ goal necessary to reduce unemployment. ${ }^{77}$ Moreover, critics argued that poverty alleviation had become a secondary preoccupation for the government by the time Mandela was retiring from office after one term. ${ }^{78}$ With the election of Thabo Mbeki as president in 1999, the ANC introduced a successor to RDP in the Growth, Employment and Redistribution (GEAR) strategy, designed to provide the 'jobs for all' that had not yet materialised in the five years since the 1994 national election campaign.

\section{Pretoria's Public Works Programme}

The Public Works Programme under GEAR had four objectives: i) the creation, rehabilitation and maintenance of physical assets that 'serve to meet the basic needs of poor communities and promote broader economic activity'; ii) the provision of training and education; iii) capacity-building of local communities for selfgovernment for sustainable development; and iv) the reduction of unemployment. ${ }^{79}$

Approximately 200,000 jobs were created annually under GEAR. ${ }^{80}$ Though multilateral financial institutions praised the government job creation scheme, many believe it had a limited impact on the country's high unemployment rate. Studies show that the jobs created annually absorbed less than $2 \%$ of the country's over eight 
million unemployed. This is because the public works scheme provided employment for a temporary period and so had not necessarily led to serious reduction in poverty. The scheme's limited impact has often been blamed on capacity constraints in both the private and public economic sectors, lack of financial sustainability, and a restricted employment period with limited spin-offs and skills transfer, which results in low employability after the individual has completed the work term. The difficulties in accessing credit has further undermined any chances the poor have to launch their own businesses. As a backdrop, it is also important to note the retrenchments and job losses caused by the restructuring of inefficient state and private enterprises after 1995: by one measure, only 500,000 new jobs, after accounting for job loss of more than 800,000 , were created ${ }^{81}$ in a period when 5 million South Africans entered the labour market. ${ }^{82}$

\section{Accelerated and Shared Growth Initiative for South Africa}

Continued income inequalities and stubborn unemployment rates prompted a reevaluation of GEAR and government's strategy on how to best address issues of poverty and inequality under the second Mbeki administration. As a result the ANC government took a more development oriented stance. In 2005, Mbeki announced the launch of the Accelerated and Shared Growth Initiative for South Africa (ASGISA) which was formally launched in 2006 by Deputy President Phumzile Mlambo-Ngcuka. ASGISA was designed to make good the ruling ANC's 2004 election pledges, namely, to halve poverty and unemployment by 2014; to improve Broad-Based Black Economic Empowerment (BBBEE) ${ }^{83}$ and accelerate employment equity, ${ }^{84}$ all within the globalised context of the new millennium. ${ }^{85}$

ASGISA entailed six broad themes. South Africa would aim to: i) increase public sector investment from $4 \%$ to $8 \%$ of GDP, mostly in public enterprises; ii) outsource investment strategies for tourism and businesses geared towards small business development and BBBEE; iii) provide skills and education programs; iv) allow intervention in the formal economy through improved access to procurement, linked to infrastructure development projects under the Expanded Public Works Programme (EPWP), ${ }^{86}$ which was designed to assist smaller black-owned businesses while improving the regulatory environment for small business; v) re-evaluate macroeconomic issues; and vi) build capacity, through public spending, of departments and agencies administering social programmes. ${ }^{87}$

Official government data shows that this initiative is succeeding in raising poor people's income, expanding access for millions of disadvantaged South Africans to government services, and expanding ownership of assets to impoverished families while generating economic growth and wealth creation. By 2008, 12 million beneficiaries were receiving social grants, up from 2.5 million in 1999. At the same time, poor households had begun receiving $50 \mathrm{kWh}$ of electricity per month and 6000 litres of water free of charge, and access to medical services improved. Government initiatives such as Early Childhood Development, Adult Basic Education and Training, and Further Education and Training (FET) have increased school attendance. Approximately $95 \%$ of South Africans also now live within $5 \mathrm{~km}$ of a health facility.

The South African government has also begun involving civil society in the delivery of social services to the poor. With a backlog of over two million houses by 
August 2010 and the ever increasing demand for housing in urban areas, the government announced the establishment of a Housing Development Agency in 2009. Since its inception, the agency has facilitated the acquisition of land for housing developments across South Africa, where more than 240,000 houses have been built for low-income families thus far. The agency, equipped with a new housing policy, has begun to involve NGOs in the establishment of 'human settlements'. For instance, the People's Housing Process (PHP) focuses on partnerships among NGOs and local community groups. The process involves beneficiaries participating in decision-making throughout the process of providing housing. This includes identifying the land, planning the settlement, and obtaining the necessary approvals and resources to begin the development. In addition, plans are well underway to issue specially-designed vouchers to NGOs which would allow members to access short training courses and building materials for use in starting their housing projects.

Meanwhile, partly due to the global economic boom, South Africa's growth accelerated to $4 \%$ per year in the period 2004-2007, well above the $1 \%$ achieved during the period 1994-2003 under GEAR. Meanwhile official unemployment figures decreased to $23 \%$ in 2007 as a result of the EPWP, after peaking at $31 \%$ in 2003. However, sceptics contend that, as with past initiatives, ASGISA is plagued by a number of disadvantages, particularly by the severe skills shortage that the country is facing.

\section{Cooperation among India, Brazil and South Africa}

These three large economies face similar challenges of meeting the aspirations of their populations, many of whom are hungry and poor. The policymakers have, more or less, successfully met the challenges of macroeconomic management and a viable balance of payments, and have made their economies more market oriented to raise sustainable growth rates. But the policy makers continue to face the arduous task of tackling long prevailing social ills, often propelled within the political system through energetic involvement by civil society organisations. Brazil has better social indicators than South Africa and India, at this juncture in history, and continues to make more progress on several fronts. But the macroeconomic situation is still relatively weak in Brazil, as it is in South Africa, and higher growth is necessary to fund social programmes. Furthermore, the problems caused by very unequal income distributions in all three IBSA countries need to be tackled.

Innovative programmes are needed to reach the poor, as growth alone may not lead to better social outcomes, particularly in Brazil and South Africa. A major problem with social programmes has been to ensure delivery of the services and benefits to the poor. While IBSA was launched in June 2003 to push for the countries' attempts to get into the Security Council, attention has shifted over time towards development and economic reform. The most recent IBSA gatherings have revealed strong commitment to issues related to the fields of technology and renewable energy. ${ }^{88}$ Food security is a common concern of enormous importance in India, Brazil and South Africa. ${ }^{89}$

Brazil's social policies have been successful as they are based on background research, successful innovative targeting and a shrewd combination of programmes. As noted earlier, Bolsa Familia works in close conjunction with Bolsa Escuela and 
under the umbrella of Zero Hunger. India's NREGS scheme has been successful in providing income to the poor, and its RTI Act has helped to improve delivery of services to the poor; digital identities would further enhance this progress. Experiences with successful and innovation social programmes can be shared among the IBSA members as well as with other developing countries.

Their membership in the G20 provides them with an opportunity to shift the focus of international economic governance to development that benefits particularly the poor, so that greater progress can be made in meeting the MDGs. As a group, they can be more effective in pushing for reform of the institutions currently in charge of international economic governance, reform not merely in voting shares but more importantly in policies on the ground supported by these institutions.

IBSA has worked to implement joint projects of interest to different countries, especially since it launched its development fund in 2004. The IBSA fund is designed to address small-scale development challenges in some of the poorest countries in the world - from Haiti to Guinea Bissau to Palestine. ${ }^{90}$ All three countries have pledged to each contribute $\$ 1$ million annually to a central fund administered by the United Nations Development Fund (UNDP) as part of its programme for South-South cooperation. Moreover, the private sector, donor agencies and international organisations have been encouraged to contribute to the fund. More importantly, the fund has helped further development cooperation in the South and link IBSA to other similar initiatives, such as the New Partnership for African Development (NEPAD). ${ }^{91}$

The underlying objective of the IBSA fund is to disseminate best practices in the alleviation of hunger and poverty, by providing improved access to health, education, and food security. In doing so, it has helped identify scalable and replicable projects that could be disseminated to interested developing countries. The fund has made it possible for non-governmental and governmental institutions in all three countries to collaborate on developmental projects.

In line with the fund's objectives, three projects have been completed to date. ${ }^{92}$ In Guinea-Bissau, the fund's 'Development of Agriculture and Livestock' has helped improve agricultural yield through the training of over 4500 farmers, including 2600 women. Begun in February 2006 and completed in April 2007, the project's budget amounted to $\$ 500,000$. Farmers received new seeds that helped improve yield and allowed agricultural production to continue throughout the rainy season. They also received training on water management and control. Meanwhile in Cape Verde, the fund's 'Support to Infrastructure in the Island of Sao Nicolau' has contributed to the rehabilitation of two health units in the isolated community of Covoada. The national government and local municipality were responsible for the project's implementation. The final budget for the project amounted to approximately $\$ 37,000$.

In Haiti, the fund administered a project on the collection and recycling of waste materials in one of the country's most impoverished and violent communities. The 'Collection of Solid Waste as a Tool to Reduce Violence in Carrefour Feilles' project had a budget of approximately $\$ 550,000$. Through the a development of a recycling, waste disposal and collection process, the project helped generate employment opportunities; reduce negative environmental impact (particularly through the introduction of cooking bricks from recycled paper products); prevent flood risk from garbage-clogged canals; and, reduce the incidence of disease. The project has provided employment opportunities to more than 285 people from the community, 
including 207 women. In addition, IBSA initiatives are under implementation in Burundi, Cambodia and the Palestinian Territories. ${ }^{93}$

IBSA's tremendous contribution to the eradication of poverty and hunger in developing states over the past seven years is widely acknowledged by the international community, particularly among development partners. In 2006, the fund was awarded the UN South-South Partnership Award. Three years later, an exhibition on the projects developed was showcased in Nairobi, New York and Washington, DC. In 2010, the fund was awarded the UN Millennium Development Goals Award by the United Nations.

There are many more opportunities for collaboration among these three nations. For instance, there are problems in the provision of education in all three countries, though the problems manifest differently (repeaters in Brazil and South Africa and dropouts in India). They could learn from each other's experiences about what has worked to prevent further wastage of human resources represented by every student that does not complete schooling. In another area, increasing FDI from these economies shows that companies have developed special assets which are best used through FDI, and so companies could benefit from joint projects. Such collaboration could push back the trend towards a stagnant manufacturing sector in all three countries. Joint IBSA ventures could be implemented in other countries, particularly developing countries. ${ }^{94}$ Indeed, the countries are already collaborating on projects in other developing countries. ${ }^{95}$

Furthermore, Brazil already gears its research for collaboration with developing countries and this could be emulated by the others. Brazil is a leader in agricultural research, and is already used as an example to help ameliorate the lagging agricultural productivity in Africa. ${ }^{96}$ The three economies have well developed financial institutions, but these operate mainly domestically. Their experience of providing credit in poor countries has the potential to be used for joint operations in other developing countries or even in developed countries. ${ }^{97}$

\section{Conclusion}

The three democracies of IBSA face similar challenges of tackling poverty and inequality. The problem before Brazil and South Africa is more severe as economic growth has been slower than in India, however disparities remain entrenched in India as well. Their experiences shows the critical importance of civil society in design and execution of programmes directed towards the poor, and this is an important factor to be kept in mind by multilateral and bilateral agencies involved in poverty alleviation projects in developing countries. The three countries can extend cooperation beyond multilateral trade negotiations, into the areas of finance and provision of services.

IBSA has made an important beginning with its fund for projects in developing countries. There is considerable scope for extending their cooperation on joint projects within the three countries as well as projects in other countries. All three have projects in other countries, and in particular are expanding their activities in Africa. As noted above, these countries are members of the G20 and together have leverage to influence the operations of the major international economic institutions. But another way to influence practices of those institutions is by their own behaviour: they and other developing countries have argued against the conditional 
lending practises of the World Bank and the International Monetary Fund (IMF), and have now demonstrated their dissatisfaction with those policies by choosing instead to accumulate large foreign exchange reserves. ${ }^{98}$ Finally, unlike traditional donors who have struggled to effectively build capacity in recipient countries, Brazil has made a good start in building research capability in other countries.

The three nations could cooperate further to share ideas for effective social welfare programmes, and join together in multilateral forums to form a powerful voice for change. Indeed, IBSA holds promise of charting new paths of cooperation among countries.

\section{Notes on contributors}

Dr Manmohan Agarwal is a visiting senior fellow at the Centre for International Governance Innovation (CIGI) and a former dean of the School of International Studies, Jawaharlal Nehru University, New Delhi, India. He has worked at the International Monetary Fund and the World Bank. He studied at the Delhi School of Economics and the Massachusetts Institute of Technology.

Hany Besada is Senior Researcher, Development Cooperation, at the North-South Institute (NSI). Previously, he was Senior Researcher and Program Leader at the Centre for International Governance Innovation (CIGI) where he oversaw the Health and Social Governance Program. He holds a BA and MA in international relations from Alliant International University in San Diego, where he specialised in peace and security studies.

Dr Lyal White is the Director of the Centre for Dynamic Markets (CDM) and a Senior Lecturer at the Gordon Institute of Business Science (GIBS), University of Pretoria. His research and services specialise in political economy issues in Africa, Asia and Latin America. Dr White has lived and worked in South Africa, Rwanda, Argentina, Colombia, Morocco and the United States.

\section{Notes}

1. The views expressed in this paper are those of the authors and do not necessarily reflect those of the institutions they are affiliated to.

2. For a broader discussion of the G20 and development see Agarwal M and J Whalley What can the G20 Contribute to Development? Waterloo, Canada: Centre for International Governance Innovation, 2010. Kharas H 'Bringing development into the G20: Overarching themes' paper prepared for the G20 Seoul International Symposium 'Towards the consolidation of the G20 summits: from crisis committee to global steering committee', 28-29 September 2010, Seoul, Korea and Maxwell S 'More of the same or something new?', 'Development of G20 summits: from crisis committee to global steering committee', 28-29 September 2010, Seoul, Korea.

3. Marglin S \& JB Schor (eds) The Golden Age of Capitalism. Oxford: Clarendon Press, 1990; and Agarwal M 'The BRICSAM countries and changing world economic power: Scenarios to 2050', Centre for International Governance Innovation, Working Paper Number 39, Waterloo, Canada, 2008. For a longer time perspective on growth of different regions see Madison A Monitoring the World Economy: 1820-1992, Paris: OECD, 1996.

4. Agarwal M 'The BRICSAM countries and changing world economic power: Scenarios to 2050', Centre for International Governance Innovation, Working Paper Number 39, Waterloo, Canada, 2008.

5. The data used in the paper is mainly from different issues of the World Development Indicators, World Development Reports and Global Development Finance, all published by the World Bank. 
6. Barro R \& X Sala I. Martin 'Convergence', Journal of Political Economy, 100, 2, 1992, pp. 223-51. Per capita incomes in Latin America and sub-Saharan Africa relative to that in the United States declined from $15 \%$ and $5 \%$ respectively in 1982, to $10 \%$ and $1.5 \%$ respectively in 2000 .

7. Agarwal M \& U Lele 'Shrinking aid, rising private capital and surging remittances', paper presented at a conference on the New Emerging Donors, organised by Professor Gregory Chin for the International research and Development Council of Canada at York University, Toronto, November 2009.

8. This was partly because prices of both energy and non-energy commodities rose by annual average of $12 \%$ between 2000 and 2008 (Calculated from data in World Bank, Global Development Finance, Washington DC: World Bank, 2009) after a prolonged decline.

9. See World Bank, Global Development Finance. Washington, DC: World Bank, 2009. Author notes that aid flows are now negligible in comparison to private capital flows in Latin America, Middle East and North Africa and East Asia, and their relative importance has declined dramatically in South Asia. Aid is still important for the SSA region where it accounts for over 5\% of GDP. Even for SSA private capital flows are more important than aid flows. MTNs have moved beyond their initial preoccupation with reducing tariffs on manufactures to deal with anti-dumping, countervailing and safeguards. Their ambit has extended to agriculture and further afield to services, trade related intellectual property rights, etc.

10. Agarwal M \& U Lele 'Shrinking aid, rising private capital and surging remittances', paper presented at a conference on the New Emerging Donors, organised by Professor Gregory Chin for the International research and Development Council of Canada at York University, Toronto, November 2009.

11. Agarwal M 'South cooperation for a better future', in Chaturvedi S, T Fues and E Sidoropoulos, Development Cooperation and Emerging Powers: New Partners or Old Patterns? London: Zed Books, forthcoming.

12. World Bank World Developments Indicators 2009. Washington, DC: World Bank.

13. Ibid.

14. World Bank World Developments Indicators 2007. Washington, DC: World Bank; and World Bank World Developments Indicators 2009. Washington, DC: World Bank.

15. World Bank World Developments Indicators 2009. Washington, DC: World Bank.

16. World Bank Global Development Finance. Washington, DC: World Bank, 2009.

17. The Economist 'Oil could transform Brazil's economy. But not necessarily for the better', 17 April 2008.

18. The share of value of exports of manufactures to value-added in manufacturing increased from 0.160, 0.316 and 0.233 in 1990 in Brazil, South Africa and India, respectively, to $0.580,0.903$ and 0.482 , respectively, in 2002 .

19. The green revolution in agriculture from the late 1960s and increased oil production and refining in the 1970s had eased India's balance of payments problems particularly in the 1970s and begun the process of acceleration of growth Agarwal M 'India', in Desai P (ed.) Going Global: Transition from Plan to Market in the World Economy. Cambridge, MA: The MIT Press, 1997.

20. United Nations Human Development Report 2006. New Delhi: United Nations Development Programme, United Nations.

21. Under each of the eight categories there are a number of indicators. We concentrate on the main indicator under each category. Some such as one under sustainability is not easily measurable while the one under international cooperation which gives the aid received by each of the developing countries is not really relevant for our analysis.

22. World Bank World Developments Indicators 2004. Washington, DC: World Bank. These are the figures before they were revised by the World Bank. The absolute ratios are higher after the revision, but the trends are similar.

23. No more recent survey has been conducted. But the better growth performance during 2000-2007 would suggest that the poverty ratio may have declined, but only slightly. Usually much faster growth is required to lower the poverty ratio substantially. World Bank World Developments Indicators 2004, Washington, DC: World Bank, 2004.

24. World Bank World Developments Indicators 2009. Washington, DC: World Bank. 
25. United Nations Human Development Report 2009. New Delhi: United Nations Development Programme, United Nations.

26. Dutt RC The Economic History of India Under Early British Rule. From the Rise of the British Power in 1757 to the Accession of Queen Victoria in 1837, Vol. I. London: Routledge, 2001; and Dutt RC The Economic History of India in the Victorian Age. From the Accession of Queen Victoria in 1837 to the Commencement of the Twentieth Century, Vol. II. London: Routledge, 2001; and Dadabhai N Poverty and Un-British Rule in India. New Delhi: Publications Division, Ministry of Information and Broadcasting, Government of India, 1901.

27. For instance, in one of his articles he wrote he would not rest till he had wiped off the tears from every eye.

28. The Committee established the official poverty line and its findings and recommendations were published as Perspectives of Development 1961-76, Implications of Planning for a Minimum Level of Living. New Delhi: Perspective Planning Division, Planning Commission, Government of India.

29. Bhagwati J \& S Chakravarty (1969) 'Contributions to Indian economic analysis', American Economic Review, 59, 4, 1969.

30. Mellor J (1976) New Economics for Growth: Strategy for India and the Developing World. Cornell: Cornell University Press, 1976.

31. Sen A Choice of Techniques. Oxford: Basil Blackwell, 1960.

32. A major aspect of this was to limit the size of holdings and then distribute the land received from farmers with large holdings to households with small holdings or no land.

33. Gopal S (1992) Jawaharlal Nehru: A Biography. New Delhi: Oxford University Press, 1992.

34. The Approach Paper to the Fifth Plan, Planning Commission Government of India, 1974, examined the implications of different rates of growth and the distribution of the incremental income among different income classes on the extent of poverty.

35. It has been argued that growth and special programmes are needed to reduce poverty. Bhagwati J The Economics of Underdeveloped Countries. London: Weidenfeld and Nicolson, 1966.

36. In the elections held recently in May 2009, a number of state governments offered to implement a number of welfare measures, prominent among them were supply of rice or some other essential goods at a subsidised price. State governments that made such promises fared well in the elections.

37. Ministry of Finance, Economic Survey 2009. New Delhi: Government of India.

38. These programmes are discussed in the annual Economic Survey published by the Finance Ministry, Government of India. One such scheme is the Swarnjayanti Gram Swarozgar Yojana which aims to bring the rural poor above the poverty line by providing them income generating assets through bank credit and government subsidy. There is a similar programme for the urban poor.

39. These would include the 'scheduled castes and scheduled tribes' (SC/ST), which are the most deprived sections of Indian society and for which the constitution includes reservations in government education institutions and government jobs, and the 'other backward classes' (OBC) to which reservations have been extended since the nineties.

40. Thaindian News 'NRHM completes five years, rural health still in disarray', 11 April 2010, accessed 15 October 2010, < http://www.thaindian.com/newsportal/health1/nrhmcompletes-five-years-rural-health-still-in-disarray_100346478.html $>$.

41. Former Prime Minister Rajiv Gandhi claimed in a public speech that only $15 \%$ of the money spent reached the intended beneficiaries.

42. Information on the working of the Act is available as yet only in local Indian newspapers. Analysts such as Jean Dreze and Aruna Roy have written, for instance, in The Hindu. See The Hindu 'Amendment to RTI Act "an obvious retrograde step"", < http://www.thehindu.com/news/national/article38610.ece $>$.

43. McCord A 'Public works as a component of social protection in South Africa', 2004, < http://www.saldru.uct.ac.za/home/index.php?/Public-Works-and-social-Protection/ public-Works-research-project-pwrp $>$ (accessed 28 November 2006). See The Economist, 'Land of Promise', 12 April 2007. 
44. Brazil's economic growth went from an average of about $10 \%$ per annum between 1965 and 1975 (peaking at 14\% growth in 1973) to dismal growth (and recession) that failed to even breach 5\% per annum between 1986 and 2004. Such high growth rates in the initial years (and policies of import substitution) helped Brazil develop certain highly competitive strategic industries in the form of the automotive sector, agriculture, mining and to a lesser extent, oil. For more background on the history of growth and development in Brazil see Piancastelli M 'Brazil's Economic Policy: Stabalisation, growth and reforms', in White L (ed), Is There an Economic Orthodoxy? Growth and Reform in Africa, Asia and Latin America. Johannesburg: SAIIA, 2006.

45. The imbalances of development in Brazil are evident both socially and geographically. As with similar cases of newly industrialised nations, real development was limited mainly to prominent industrial areas of clusters. In the case of Brazil, Sao Paulo and Rio de Janeiro attracted large portions of investment, while less developed rural areas in the interior or along the Amazon in the North remained off the economic radar.

46. US Department of State 'Background note: Brazil', 9 September 2010, accessed 17 October 2010, < http://www.state.gov/r/pa/ei/bgn/35640.htm > .

47. See United Nations United Nations Development Report, $2006<\mathrm{http}: / / \mathrm{hdr}$.undp.org/en/ reports/global/hdr2006>.

48. This includes a larger portion of the national budget allocated toward education and research, a higher enrolment in primary and secondary schooling and a steady increase in literacy rates. See <http://web.worldbank.org/WBSITE/EXTERNAL/COUNTRIES/LA CEXT/BRAZILEXTN/0,,menuPK:322367 pagePK:1141132 piPK:141109 theSitePK:322 $341,00 . \mathrm{html}>$ for some empirical findings in this regard. The UNDP's International Poverty Centre <http://www.ipc-undp.org/PubsearchResult.do $>$ has conducted extensive research and has numerous published studies that explain the progress and trajectory in Brazil vis-à-vis social programmes and socio-economic inclusion more broadly.

49. The Economist 'Happy families: An anti-poverty scheme invented in Latin America is winning converts worldwide', 7 February 2008, accessed 16 October 2010, <http:// www.economist.com/world/la/displaystory.cfm?story_id $=10650663>$.

50. Much of the information about Zero Hunger used in this section is based on a detailed study by Walter Belik and Mauro Del 'Brazil's zero hunger program in the context of social policy', paper presented at the International Conference of Agricultural Economists, Durban, South Africa, August 2003.

51. See Americas.org, 'Brazil's Zero Hunger project brings food to 15 million people', 26 March 2004.

52. 'Cash transfers: Lessons from Africa and Latin America', Poverty in Focus, International Poverty Centre, Number 15, August 2008.

53. The primary responsibility for the programme falls on so-called 'Local Committees'. They identify and select the needy households. They also arrange and monitor the next phase of resource transfers, ensuring that the entire bundle of social programmes is carried out in conjunction with Zero Hunger. This includes the maintenance of children at school (which is also sustained through another programme called Bolsa Escola), attendance at literacy courses for illiterate adults, participation at capacity building courses, community services, proof of public health assistance (i.e. children's vaccinations) and proof that the food stamps are being used to purchase food.

54. This was a result of a study conducted by Brazil's Applied Economic Research Institute (IPEA) (www.ipea.org.br).

55. The Economist 'Happy families: An anti-poverty scheme invented in Latin America is winning converts worldwide', 7 February 2008, <http://www.economist.com/world/la/ displaystory.cfm?story_id $=10650663>$ (accessed 16 October 2010).

56. The first round of elections in early October 2010 did not give Lula's chief of staff, Dilma Rousseff, the required majority to claim victory, and the run-off results were not available at time of going to press.

57. Cardenas M \& E Levy-Yeyati, 'Brookings Latin America economic perspectives'. The Brookings Institute, Latin America Initiative, September 2010.

58. Besada H 'Fragile stability: Post-Apartheid South Africa'. CIGI Working Paper, no. 27 (August), Waterloo, The Centre for International Governance Innovation, 2007. 
59. Instituted by the then South African National Party (NP) in 1948, apartheid (separateness) sought the separate existence of South Africa's races. Apartheid provided the policy framework for the maintenance of minority rule through the institutionalised segregation of the country along racial lines. Cochran E 'The pivotal stage: post apartheid South Africa', Parameters: US Army War College Quarterly, 30, 4, 2001, pp. 83-101.

60. The unequal income distribution is reflected in the Gini co-efficient which was 0.665 at the time of the dismantling of apartheid in 1994 and increased to 0.68 three years later. Marais H South Africa? Limits to Change: The Political Economy of Transformation. London and Cape Town: Zed Books and the University of Cape Town Press, 1998, p. 106.

61. United Nations Human Development Report 2004. New Delhi: United Nations Development Programme, United Nations.

62. Data obtained from the 1995 Income and Expenditure Survey suggests that approximately $40-50 \%$ of the population is poor, while $25 \%$ could be considered as extremely poor.

63. Woolward I and M Leibbrandt 'Measuring poverty in South Africa', in Bhorat $\mathrm{H}$ et al. Fighting Poverty: Labour Markets and Inequality in South Africa. Cape Town: University of Cape Town Press, 2001, p. 56, base their analysis on Household Subsistence Level of \$1/day, or R3509 and 2200 per annum per adult in 1995 Rand prices. Leibbrandt M, I Woolard \& H Bhorat 'Understanding contemporary household inequality in South Africa', in Bhorat H, M Leibbrandt, M Maziya, S van der Berg \& I Woolard, Fighting poverty: Labour Markets and Inequality in South Africa. Cape Town: University of Cape Town Press, 2001.

64. Besada H 'Fragile stability: Post-Apartheid South Africa'. CIGI Working Paper, no. 27 (August), Waterloo, The Centre for International Governance Innovation, 2007. For a more in-depth discussion of South Africa's Apartheid legacy, please consult Besada H 'Enduring political divides in South Africa', CIGI Technical Paper, August 2007.

65. Poggenpoel S \& L Oliver Investigating the Implications of Ten Years of Democracy for Women: The Role of the Department of Social Development, 2005, < http:// www.sarpn.org.za/documents/d0000866/index.php > (accessed 28 November 2006).

66. Sewpaul V \& D Hölscher D 'Against the odds: Community-based interventions for children in difficult circumstances in post apartheid South Africa', in Dominelli L (ed.) Revitalizing Communities. Hampshire: Ashgate, 2006.

67. Poggenpoel S \& L Oliver Investigating the Implications of Ten Years of Democracy for Women: The Role of the Department of Social Development, 2005, <http:// www.sarpn.org.za/documents/d0000866/index.php > (accessed 28 November 2006).

68. Weyers ML 'The eight habits of highly effective community social workers: A South African perspective', Social Work/Maatskaplike Werk 43, 4, 2007, pp. 1-15.

69. Zungu ZM 'An investigation into factors contributing to the success or failure of income generating projects in Nongoma, KwaZulu Natal', Masters dissertation, Durban, School of Social Work and Community Development, University of KwaZulu Natal, 2006.

70. Ibid.

71. Gray M 'The progress of social development in South Africa', International Journal of Social Development Issues, 24, 15, 2006, pp. 4-14.

72. Patel L Social Welfare and Social Development. Cape Town: Oxford University Press, 2005.

73. Sloth-Nielsen J Realizing the Rights of Children Growing Up in Child-Headed Households: A Guide to Policies and Social Advocacy. Cape Town: Community Law Centre, University of the Western Cape, 2003.

74. Taylor Committee 'Transforming the Present: Protecting the Future', Draft Consolidated Report of the Committee of Inquiry into a Comprehensive System of Social Security for South Africa, Pretoria, National Department of Social Development, 2002.

75. Seidman-Magketla N 'Overview of the economy'. Unpublished paper, 2001. SARB, Quarterly Bulletins, Various issues 1990-2002, South African Reserve Bank, Pretoria.

76. Venter L When Mandela Goes. Johannesburg: Transworld Publishers Ltd, 1997.

77. Department of Finance 'Budget review'. Pretoria: Government Printers, 2000. Michael A 'Chronic poverty in South Africa: incidence, causes and policies', World Development, 31, 3, 2003, pp. 473-90. 
78. Midgley J 'South Africa: The challenge of social development', International Journal of Social Welfare, 10, 4, 2001, pp. 267-75. Adelzadeh A, C Alvillar \& C Mather 'Poverty elimination, employment creation and sustainable livelihoods in South Africa'. NIEP Research Articles no. 12, 1998.

79. McCord A op. cit.

80. Skewyiya Z' 'Housing input to the Social Cluster: Media Briefing', Briefing by Minister of Social Development at the Parliamentary Media Briefing Week, Cape Town, 7 February 2006.

81. SARB (South African Reserve Bank) 'Economic and financial data for South Africa'. 2001, < http://www.sarpn.org.za/documents/d0000649/P661-Poverty-report36.pdf > . SeidmanMagketla N 'Overview of the economy'. Unpublished paper, 2001. SARB, Quarterly Bulletins, Various issues 1990-2002, South African Reserve Bank, Pretoria.

82. Landman J 'Breaking the grip of poverty and inequality in South Africa: 2004-2014', 2003, accessed 15 June 2004, <http://www.sarpn.org.za/documents/d0000649/P661Povertyreport3b.pdf?>. Bhorat H 'Labor market challenges in post-Apartheid South Africa', paper presented to the EFSA Colloquium, Cape Town, October 2003. Bhorat H \& R Cassim 'How can the SA steam engine become a Ferrari?' South African Labor Bulletin, 28, 2, 2004, pp. 21-33.

83. BBBEE was designed to help distribute wealth across as broad spectrum of South Africa's society as possible. It is based on seven pillars; equity ownership, management, employment equity, skills development, preferential procurement, enterprise development and residual element/corporate social investment. The programme reached much further than other affirmative action policies in place in other states. It sets quotas for black ownership of companies across key economic sectors, including agriculture, financial services, information technology, tourism and mining. However, there have been growing criticisms of the programme in that many beneficiaries are politically connected to the ruling party and so it enriches only small, politicallyconnected, black elite.

84. African National Congress Manifesto 2004: A People's Contract to Create Work and Fight Poverty. Johannesburg: ANC, 2004.

85. Daniel J, R Southhall \& J Lutchman 'Introduction: President Mbeki's second term: Opening the golden door?' in Daniel J, R Southhall \& J Lutchman (eds) State of the Nation: South Africa, 2004-2005. Cape Town: HSRC Press, 2004; Gelb S 'An overview of the South African economy', in Daniel J, R Southhall \& J Lutchman (eds) State of the Nation: South Africa, 2004-2005. Cape Town: HSRC Press, 2004; Southhall R 'Introduction: Can South Africa be a developmental state?' in Buhlungu S, J Daniel, R Southall \& J Lutchman (eds) State of the Nation: South Africa, 2005-2006. HSRC Press, Cape Town, 2006.

86. ASGISA involved a public work programme which amounted to R370 billion, mainly in the infrastructure and tourism sectors. The programme sought to offer public employment, particularly for unskilled labourers, in the field of government infrastructure projects that would create employment to one million South Africans.

87. Republic of South Africa The Accelerated and Shared Growth Initiative for South Africa: A Summary. Pretoria: Government Printer, 2006.

88. <http://www.ipc-undp.org/ipc/doc/ibsa/papers/ibsa3.pdf $>$.

89. <http://www.dfa.gov.za/docs/2004/ibsa0305a.htm >, <http://search.japantimes.co.jp/ cgi-bin/e20100628a1.html > and < http://www.itamaraty.gov.br/temas-mais-informacoes/ saiba-mais-ibas/documentos-emitidos-pelos-chefes-de-estado-e-de/5Lh-ibas-ministerialmeeting-communique $>$.

90. The IBSA Fund, 13 January 2010, accessed 17 October 2010, <http://www.ibsatrilateral.org/index2.php?option $=$ com_content\&do_pdf $=1 \&$ id $=29>$.

91. Cape Town Ministerial Communique, March 2005, accessed 17 October 2010, < http:// web.archive.org/web/20070914120518/http://www.ibsa-trilateral.org/cape_town_ministerial. htm $>$.

92. The IBSA Fund, 13 January 2010, accessed 17 October 2010, <http://www.ibsatrilateral.org/index2.php?option $=$ com_content\&do_pdf $=1 \&$ id $=29>$.

93. Ibid. 
94. Enterprises in developing countries are developing products more suited to the conditions in developing countries and the low purchasing power of the average consumer. Prahalad CK and RA Mashelkar 'Innovations' holy grail', Harvard Busines Review, July-August 2010, pp. 132-41.

95. On joint IBSA ventures with other countries <http://www.itamaraty.gov.br/temasmais-informacoes/saiba-mais-ibas/documentos-emitidos-pelos-chefes-de-estado-e-de/5Lhibas-ministerial-meeting-communique $>, \quad<$ http://www.ipc-undp.org/ipc/doc/ibsa/pa pers/ibsa3.pdf $>$ and < http://www.twnside.org.sg/title2/resurgence/2010/238-239/cover $05 \mathrm{htm}>$.

96. The Economist 'The miracle of the cerrado', 28 August 2010, pp. 46-48.

97. The experience of Grameen Bank in providing micro finance in Bangladesh is being used to provide credit to the poor in New York City.

98. Grover I 'India's transition from recipient to donor', Norrag News Online, September 2010, < http://www.norrag.org/issues/article/1333/en/india_s-transition-form-recipientto-donor.html?PHPSESSID=ea018508137f54ef257a1f17bbe581fe $>\quad$ (accessed 16 November 2010); Trinity of the South: Potential of India-Brazil-South Africa (IBSA) Partnership, in Gushne KM, BRIC Rebounding from the Global Financial Crisis, 2009, $<$ http://kmgadvisors.com/wp-content/uploads/2009/06/bric_rebound_kmgadvisors_0609_ summaryl.pdf $>$ (accessed 16 November 2010); and 'Global Financial reforms and developing countries', Third World Resurgence 238/239, June-July 2010, pp. 34-37, $<$ http://www.twnside.org.sg/title2/resurgence/2010/238-239/cover05.htm > (accessed 16 November 2010). 